\title{
Analisis Kualitas Pelayanan Publik Rawat Inap Pada Badan Layanan Umum Rumah Sakit Umum Daerah Kota Subulussalam
}

\author{
Analysis of Public Service Quality Institution in Public Service \\ Agency Regional General Hospital Kota Subulussalam \\ Khainuddin ${ }^{1}$, Heri Kusmanto ${ }^{2}$ \& Isnaini ${ }^{3}$
}

Staf Pengajar Magister Program Studi Administrasi Publik, Universitas Medan Area

\begin{abstract}
Abstrak
Cara meningkatkan kualitas pelayanan pada pasien rawat inap pada Badan Layanan Umum Rumah Sakit Umum Daerah Kota Subulussalam, dengan tujuan penelitian: 1) untuk mengetahui dan menganalisis kualitas pelayanan pada pasien rawat inap pada Badan Layanan Umum Rumah Sakit Umum Daerah Kota Subulussalam, 2) untuk mengetahui dan menganalisis cara meningkatkan kualitas pelayanan pada pasien rawat inap pada Badan Layanan Umum Rumah Sakit Umum Daerah Kota Subulussalam.Adapun metode penelitian yang digunakan adalah metode deskriptif, sedangkan teknik analisis data menggunakan deskriptif kualitatif. Dari hasil penelitian ini menunjukkan bahwa kualitas pelayanan publik pada Rawat Inap RSUD Kota Subulussalam tergolong pada kategori baik. Bukti fisik kebersihan ruangan cukup baik, kepercayaan terhadap pelayanan cukup baik, ketanggapan cukup baik, kompetensi tenaga kesehatan cukup baik, kesopanan cukup baik, kredibilitas cukup baik, keamanan cukup dan upaya tenaga kesehatan untuk memahami penyakit pasien juga cukup baik. Tetapi masih ada unsur pelayanan yang kurang baik, yaitu ketersediaan fasilitas yang kurang baik, kurang Imformasi dalam perhitungan biaya, serta komunikasi yang tidak bagus. Untuk meningkatkan pelayanan maka perlu dilakukan perbaikan terhadap fasilitas, memperbaiki prosedur perhitungan biaya pengobatan, menyediakan sumber informasi yang dapat memudahkan pasien untuk mengetahui jenis layanan yang terdapat pada rumah sakit. Kata Kunci: Kualitas Pelayanan, Rawat Inap
\end{abstract}

\section{Abstract}

How to improve the quality of care for inpatients at the Public Service Agency Subulussalam City Regional Hospital, with the aim of research: 1) to find out and analyze the quality of care in inpatients at the Public Service Agency of the Regional General Hospital of Subulussalam City, 2) to find out and analyze ways to improve the quality of care for inpatients at the Public Service Board of the Regional General Hospital Subulussalam City. The research method used is descriptive method, while the data analysis technique uses qualitative descriptive. The results of this study indicate that the quality of public services in the Inpatient of RSUD Subulussalam Municipality is in the good category. The physical evidence of room cleanliness is quite good, trust in service is quite good, responsiveness is quite good, competency of health personnel is quite good, politeness is quite good, accessibility is quite good, security is sufficient and efforts by health personnel to understand the patient's illness are also quite good. But there are still elements of poor service, namely the availability of poor facilities, lack of honesty in calculating costs, and poor communication. To improve service, it is necessary to improve the facilities, improve the procedure for calculating medical expenses, provide a source of information that can facilitate patients to find out the types of services available at the hospital. Keywords: Service Quality, Inpatient Care, Hospital

How to Cite: Khainuddin, Kusmanto H, Isnaini. Analisis Kualitas Pelayanan Publik Rawat Inap Pada Badan Layanan Umum Rumah Sakit Umum Daerah Kota Subulussalam. Strukturasi: Jurnal Ilmiah Magister Administrasi Publik, 1(1) 2020: 22-31,

*E-mail: $\underline{\text { Khainuddin@gmail.com }}$ 


\section{PENDAHULUAN}

Masalah kesehatan menjadi problem utama yang dijumpai sehari-hari. Setiap hari banyak masyarakat yang dating kerumah sakit untuk berobat (Simanjuntak, 2016). Semakin banyak masyarakat datang kerumah sakit maka semakin tinggi pula tuntutan rumah sakit untuk meningkatkan kualitas pelayanannya. Rumah sakit harus peduli dengan kualitas pelayanan yang diberikan kepada pasien agar rumah sakit mengetahui seberapa puas pasien dengan kualitas pelayanan di rumah sakit (Prastika, 2017). Potensi rumah sakit meliputi seluruh sumber yang dimiliki termasuk semua sumber daya rumah sakit sebagai input, manajemen sebagai proses dan produk pelayanan keehatan sebagai outcome diharapkan dapat menjual produk yang dihasilkan tersebut. Agar tetap dapat bersaing, maka produk yang dihasilkan harus bermutu dan sesuai dengan kriteria kebutuhan masyarakat. Dalam menentukan konsumen sasaran, rumah sakit perlu memahami perilaku konsumen dalam proses pengambilan keputusan (Dumpapa, 2010).

Salah satu instansi yang memasarkan jasa kepada konsumen adalah instansi pelayanan kesehatan. Pelayanan kesehatan menimbulkan persaingan antara penyedia pelayanan kesehatan termasuk diantaranya adalah Rumah Sakit. Dengan adanya persaingan antar Rumah Sakit yang semakin tinggi disertai dengan banyaknya pembangunan klinik baru maka klinik perlu terus mengembangkan diri dengan menyelenggarakan pelayanan yang bermutu dan meningkatkan kualitas baik pelayanan medic maupun pelayanan administrasinya guna memberikan kepuasan terhadap pasien. Rumah sakit sebagai salah satu fasilitas pelayanan kesehatan memiliki peran yang sangat strategis dalam upaya mempercepat peningkatan derajat kesehatan masyarakat Indonesia. Menurut Peraturan Menteri Kesehatan Republik Indonesia Nomor 340/MENKES/PER/III/2010, dikemukakan bahwa rumah sakit adalah institusi pelayanan kesehatan yang menyelenggarakan pelayanan kesehatan perorangan secara paripurna yang menyediakan pelayanan rawat inap, rawat jalan, dan gawat darurat.

Upaya kesehatan ditujukan untuk peningkatan kualitas pelayanan, pemerataan dan jangkauan pelayanan kesehatan. Mutu pelayanan kesehatan masyarakat perlu terus ditingkatkan untuk meningkatkan derajat kesehatan masyarakat karena terwujudnya keadaan sehat merupakan kehendak semua pihak. Untuk mewujudkan keadaan sehat tersebut banyak hal perlu dilakukan, salah satu upaya yang dinilai mempunyai peranan yang cukup penting yakni penyelenggaraan pelayanan kesehatan. Pemberian pelayanan kepada pasien akan berjalan dengan baik apabila dilakukan oleh petugas dengan sikap yang ramah, sopan tertib, dan penuh rasa tanggung jawab serta mempunyai ilmu pengetahuan dan keterampilan. Rumah sakit sebagai penyedia pelayanan dituntut agar selalu meningkatkan kualitas pelayanannya tanpa membedakan latar belakang sosial dan penanggung biaya pasien karena pasien yang bertindak sebagai konsumen yang menggunakan pelayanan tersebut ingin mendapatkan pelayanan yang berkualitas sehingga menciptakan kepuasan bagi pasien.

Rumah Sakit Umum Daerah Kota Subulussalam adalah rumah sakit milik Pemerintah Daerah Kota Subulussalam yang beralamat di Jln. Hamzah Fansuri Dusun Rahmah Kampong Subulussalam Barat Kecamatan Simpang Kiri Kota Subulussalam. Dalam rangka peningkatan pelaksanaan pelayanan kesehatan khususnya bagi 
masyarakat Kota Subulussalam dan umumnya kepada masyarakat di kabupatenkabupaten yang terletak di kawasan Pantai Barat dan Selatan Aceh, maka Pemerintah Kota Subulussalam telah mengambil kebijakan strategis di bidang kesehatan dengan mengupayakan pembangunan Rumah Sakit Umum Daerah RSUD di Kota Subulussalam dimana dengan adanya keberadaan Rumah Sakit Umum Daerah RSUD tersebut diharapkan akan dapat mengoptimalkan pelayanan kepada seluruh lapisan masyarakat.

Berdasarkan pengamatan pendahuluan diketahui bahwa masih ada masyarakat yang kecewa dengan pelayanan pihak rumah sakit karena pelayanan yang kurang baik. Dalam hal ini pasien pada Unit Rawat Inap RSUD Kota Subulussalam masih kurang puas dalam memperoleh pelayanan rumah sakit, yaitu masih kurangnya fasilitas, kurangnya informasi yang dapat diperoleh mengenai layanan rumah sakit dan proses pelayanan yang cenderung lambat. Disamping itu, keluarga pasien juga sering mengeluh dalam perhitungan biaya dimana biaya yang dibebankan kepada pasien melebihi perkiraan, sehingga dapat menimbulkan komplain dari keluarga pasien. Pasien kurang percaya dengan kejujuran pihak rumah sakit dalam proses pengobatan karena terdapat banyak masyarakat yang kecewa.

\section{METODE PENELITIAN}

Penelitian ini menggunakan metode deskriptif kualitatif. Di mana peneliti mendeskripsikan apa yang dilihat, didengar, dirasakan dan ditanyakan. Penelitian dilakukan pada Badan Layanan Umum Rumah Sakit Umum Daerah Kota Subulussalam yang beralamat di Jl. Hamzah Fansyuri Kampong Subulussalam Barat Kec. Simpang Kiri Kota Subulussalam Aceh 24782. Penelitian dilakukan dari Bulan Januari sampai dengan Bulan Februari 2019. Dalam penelitian ini, jumlah populasi sebanyak 7.504 pasien pada tahun 2018. Berdasarkan rumus slovin dapat diketahui jumlah sampel penelitian adalah: $\mathrm{n}=7.504 /\left(1+7.504(0,1)^{2}\right)=98,68$ dibulatkan menjadi 99 orang. Sedangkan informan yang digunakan sebanyak 3 orang yaitu Kepala Unit Rawat Inap, Perawat dan Keluarga Pasien.

Teknik pengumpulan data dalam penelitian ini adalah penelitian kepustakaan dan penelitian lapangan dengan menggunakan teknik kuesioner, wawancara dan observasi. Untuk membantu dalam menganalisa data, maka penelitian ini menggunakan teknik penentuan skor. Teknik pengukuran skor yang digunakan adalah skala likert untuk menilai jawaban responden.

\section{HASIL DAN PEMBAHASAN}

\section{Sejarah Singkat Berdirinya Rumah Sakit Umum Daerah Kota Subulussalam}

Rumah Sakit Umum Daerah Kota Subulussalam adalah rumah sakit milik Pemerintah Daerah Kota Subulussalam yang beralamat di Jln. Hamzah Fansuri Dusun Rahmah Kampong Subulussalam Barat Kecamatan Simpang Kiri Kota Subulussalam. Dalam rangka peningkatan pelaksanaan pelayanan kesehatan khususnya bagi masyarakat Kota Subulussalam dan umumnya kepada masyarakat di kabupatenkabupaten yang terletak di kawasan Pantai Barat Aceh, maka Pemerintah KotaSubulussalam telah mengambil kebijakan strategis di bidang kesehatan dengan 
mengupayakan pembangunan Rumah Sakit Umum Daerah RSUD di Kota Subulussalamdimana dengan adanya keberadaan Rumah Sakit Umum Daerah RSUD tersebut diharapkan akan dapat mengoptimalkan pelayanan kepada seluruh lapisan masyarakat.

Pembangunan Rumah Sakit Umum Daerah Kota Subulussalam pada awalnya didasarkan dari Surat Rekomendasi mendirikan RSIA Kota Subulussalam dari Dinas Kesehatan Kota Subulussalam Nomor: 442/534/Dinkes-SS/2011 namun dalam perjalanannya lebih banyak pasien umum yang membutuhkan pelayanan kesehatan dan belum adanya rumah sakit umum daerah maka dirubahlah RSIA Kota Subulussalam menjadi RSUD Kota Subulussalam ditetapkan kelas C dan beroperasi mulai Maret 2015. Pelayanan RSUD Kota Subulussalam meliputi pelayanan IGD, apotek, pemeriksaan laboratorium, poliklinik umum, poliklinik gigi dan Ruang Verlos Kamer atau Ruang Bersalin.

Rumah Sakit Umum Daerah Kota Subulussalam memiliki luas area 72.545 M2dan lahan yang telah digunakan hanya 75 untuk gedung dan fasilitas rumah sakit, sedangkan lahan kosong yang masih tersedia selanjutnya digunakan untuk pengembangan rumah sakit. Seiring berjalannya waktu, RSUD Kota Subulussalam terusmelakukan pengembangan pelayanan yang diharapkan dapat memenuhi kebutuhan masyarakat Kota Subulussalam akan pelayanan kesehatan yang terbaik.

\section{Kualitas Pelayanan Publik Unit Rawat Inap Badan Layanan Umum RSUD Kota Subulussalam}

Bukti Fisik (Tangibles), Bukti fisik dalam pelayanan pada rumah sakit terlihat dari kondisi fisik fasilitas layanan, termasuk juga kondisi ruangan dan kebersihan tempat perawatan pasien. Ruangan rawat inap harus dilengkapi dengan berbagai fasilitas fisik dan kebersihan sangat berpengaruh terhadap proses penyembuhan pasien.

Dari hasil wawancara dijelaskan bahwa ketersediaan fasilitas fisik pada rumah sakit masih tergolong kurang, dimana tempat tidur masih kurang banyak sementara alat kipas angin untuk mendingin ruangan juga masih kurang memadai. Disamping itu, rumah sakit juga belum dapat menyediakan ruangan VIP untuk pasien yang menghendaki ruang perawatan yang lebih pribadi. Dengan demikian dapat disimpulkan bahwa ketersediaan fasilitas pada Unit Rawat Inap RSUD Kota Subulussalam masih kurang baik, sehingga kurang mencerminkan pelayanan yang berkualitas.

Kepercayaan (Reliability), Kepercayaan merupakan bentuk keyakinan bahwa pelayanan yang diberikan pada rumah sakit telah dilakukan secara akurat, dimana jenis penyakit dapat diketahui secara lebih pasti yang disertai dengan tindakan penanganan atau pengobatan yang paling tepat. Diagnosis dan pengobatan merupakan inti kualitas pelayanan pada rumah sakit.

Dari hasil wawancara dapat dijelaskan bahwa proses diagnosis pada rumah sakit telah dapat dilakukan dengan akurat, karena didukung dengan peralatan medis yang memadai yang disertai dengan kemampuan menganalisa gejala penyakit untuk mengetahui jenis dan penyebabnya. Dengan demikian dapat disimpulkan bahwa proses diagnosis pada Unit Rawat Inap RSUD Kota Subulussalam sudah dilakukan dengan baik, 
sehingga mencerminkan pelayanan yang berkualitas. Menurut Bustan (2006:72) bahwauntuk menegakkan diagnosis suatu penyakit ketiga prosedur ini dianggap sebagai suatu prosedur lengkap untuk mencapai suatu diagnosis pasti atau benar. Namun tidaklah mudah untuk untuk melakukan ketiga prosedur dalam menegakkan diagnosa karena:

a) Memerlukan waktu yang lama, sementara diagnosis diharapkan segera.

b) Faktor biaya pelaksanaan, khususnya pemeriksaan dengan menggunakan alat-alat laboratorium modern yang mahal.

c) Adanya subjektivitas dan kelemahan dari masing-masing cara.

Ketanggapan (Resvonsiveness), Pelayanan yang cepat tanggap sangat penting pada rumah sakit karena setiap pasien membutuhkan penanganan yang cepat untuk menghindari semakin berkembangnya penyakit yang diderita oleh pasien. Dalam hal ini, setiap pasien harus segera ditangani (diobati), dan semua keluhan selama dalam perawatan harus segera ditanggapi sebagai upaya mencapai penyembuhan yang lebih cepat.

Dari hasil wawancara dapat dijelaskan bahwa tenaga kesehatan pada rumah sakit telah memberikan penanganan yang cepat kepada setiap pasien yang berobat di rawat inap, tanpa melakukan pembedaan antara satu pasien dengan pasien yang lain, karena terdapat kesadaran yang kuat bagi tenaga kesehatan bahwa mereka setiap penyakit jika tidak ditangani dengan cepat dapat berkembang hingga mengancam keselamatan pasien. Dengan demikian dapat disimpulkan bahwa proses perawatan pasien pada Unit Rawat Inap RSUD Kota Subulussalam telah menerapkan proses pelayanan yang cepat, sehingga mencerminkan pelayanan yang berkualitas.

Kompetensi (Competence), Kompetensi merupakan gambaran mengenai keahlian dan pengetahuan tenaga kesehatan dalam memberikan pengobatan kepad pasien. Tenaga kesehatan dikatakan berkompeten apabila memiliki pengetahuan yang luas mengenai kesehatan serta mempunyai keahlian di bidang pengobatan.

Dari hasil wawancara dapat dijelaskan bahwa tenaga kesehatan pada rumah sakit telah mempunyai keahlian yang baik dalam pengobatan/pemulihan, dimana mereka telah mendapat pendidikan yang memadai serta pengalaman praktek yang cukup lama. Tenaga kesehatan juga aktif mempelajari pengobatan dari berbagai sumber ilmiah yang dapat menambah keahlian mereka di bidang pengobatan. Dengan demikian dapat disimpulkan bahwa tenaga kesehatan pada Unit Rawat Inap RSUD Kota Subulussalam telah mempunyai keahlian yang baik dalam pengobatan, sehingga cukup mendukung bagi pelayanan yang berkualitas.

Kesopanan (Courtesy), Kesopanan tentu akan menimbulkan suasana yang baik atau kondusif dalam hubungan antara tenaga kesehatan dengan pasien, yang dapat ditunjukkan dengan bersikaf sopan serta menghargai pasien serta keluarganya. Sikaf kesopanan tersebut tentu akan menciptakan suasana yang mendukung dalam berkomunikasi, sehingga memudahkan aliran informasi antara tenaga kesehatan dengan pasien.

Dari hasil wawancara dapat dijelaskan bahwa tenaga kesehatan pada rumah sakit telah menunjukkan sikap yang selalu menghargai pasien, sehingga pasien menjadi lebih 
betah selama menjalani perawatan di rumah sakit. Menurut keluarga pasien, tenaga kesehatan tidak pernah menunjukkan sikap sepele dan selalu saling menjaga untuk tetap menunjukkan sikap saling menghargai antara tenaga kesehatan dengan pasien dan keluarganya. Dengan demikian dapat disimpulkan bahwa tenaga kesehatan pada Unit Rawat Inap RSUD Kota Subulussalam telah menunjukkan menghargai pasien, sehingga mencerminkan pelayanan yang berkualitas.

Kredibilitas (Credibility), Kredibilitas menunjukkan keyakinan terhadap kejujuran yang diberikan pihak rumah selama dalam proses perawatan pasien, yang sangat dibutuhkan untuk menghindari salah persepsi antara pasien dengan rumah sakit. Dalam hal ini, pihak rumah sakit harus menunjukkan kejujuran dan transparansi mengenai jenis pengobatan yang diberikan, dan jujur dalam perhitungan biaya pengobatan.

Dari hasil wawancara dijelaskan bahwa rumah sakit belum menyediakan informasi secara baik tentang perhitungan biaya pengobatan, sehingga cenderung keluarga pasien merasa ragu. Sebelum dilakukan pengobatan dan mendapatkan pelayanan rawat inap, biasanya biaya pengobatan diperkirakan agar keluarga pasien mempunyai persiapan dalam hal biaya karena biaya tersebut harus dibayar walaupun pasien belum sembuh atau harus dirujuk ke rumah sakit lain yang peralatannya lebih baik. Dalam hal ini tarif jasa rumah sakit tidak diinformasikan melalui leaflet dan papan pengumuman, padahal itu penting untuk memudahkan pasien mengetahui biaya jasa rumah sakit. Dengan demikian dapat disimpulkan bahwa pihak RSUD Kota Subulussalam kurang mengimformasikan dalam perhitungan biaya pengobatan, sehingga tidak mencerminkan pelayanan yang berkualitas.

Keamanan (Security), Keamanan menunjukkan keyakinan terhadap layanan yang bebas dari bahaya, sehingga benar-benar berisiko untuk memperparah penyakit pasien karena salah penanganan. Dalam hal ini, rumah sakit harus menghindari mal praktek serta memberikan pengobatan yang meyakinkan kepada pasien.

Dari hasil wawancara dapat dijelaskan bahwa rumah sakit selalu memberikan pengobatan atau pelayanan yang bebas dari mal praktek. Pengobatan yang diberikan telah diuji secara ilmiah, dan juga telah dibuktikan dari pengalaman tenaga kesehatan bahwa pengobatan tersebut mampu menyembuhkan sesuai dengan jenis penyakitnya. Dengan demikian dapat disimpulkan bahwa pengobatan pada Unit Rawat Inap RSUD Kota Subulussalam tidak terdapat pelayanan mal praktek, sehingga mencerminkan pelayanan yang berkualitas.

Kemudahan Mengakses (Acces), Kemudahan mengakses merupakan jenis layanan informasi yang memudahkan adanya kontak hubungan yang dapat digunakan oleh pasien atau keluarganya. Dalam hal ini, rumah sakit harus menyediakan jenis informasi dapat memudahkan pasien mengetahui jenis layanan pada rumah sakit, serta mengupayakan agar tenaga kesehatan dapat dihubungi pada saat diperlukan.

Dari hasil wawancara dapat dijelaskan bahwa rumah sakit tidak menyediakan sumber informasi yang dapat memudahkan pasien untuk mengetahui jenis layanan yang terdapat pada rumah sakit. Sumber informasi pada rumah sakit adalah petugas yang secara khusus untuk memberikan informasi kepada pasien atau keluarganya, sedangkan informasi dalam bentuk tercetak yang dapat dibaca oleh pasien, tidak ada. Dengan 
demikian dapat disimpulkan bahwa penyediaan sumber infomasi pada Unit Rawat Inap RSUD Kota Subulussalam masih tergolong kurang baik, sehingga kurang mencerminkan pelayanan yang berkualitas.

Komunikasi (Communication), Komunikasi antara pasien atau keluarganya dengan tenaga kesehatan merupakan bagian penting dalam penyembuhan pasien, karena sebagian besar dari informasi untuk keperluan diagnosis diperoleh dari gejala fisik yang dirasakan oleh pasien. Oleh karena itu, tenaga kesehatan harus dapat berkomunikasi dengan bahasa yang mudah dimengerti serta mampu menjalin konuminasi yang harmonis.

Dari hasil wawancara dapat dijelaskan bahwa tenaga kesehatan pada rumah sakit sering mengungkapkan bahasa yang tidak dimengerti oleh pasien atau keluarganya, terutama jika menyangkut istilah kesehatan. Kondisi tersebut tentu akan menyulitkan karena pasien atau keluarganya tidak dapat menjawab dengan baik mengenai kondisi yang dialami atau dirasakan pasien sehubungan dengan penyakitnya. Dengan demikian dapat disimpulkan bahwa tenaga kesehatan pada Unit Rawat Inap RSUD Kota Subulussalam kurang mampu berkomunikasi dengan menyederhanakan bahasa medis menjadi bahasa yang mudah dipahami pasien, sehingga kurang mencerminkan pelayanan yang berkualitas.

Pemahaman (Understanding), Pemahaman dalam pelayanan merupakan segala upaya dilakukan untuk benar-benar memahami keadaan atau kondisi penyakit pasien, serta upaya yang sungguh-sungguh untuk menyembuhkannya.

Dari hasil wawancara dapat dijelaskan bahwa tenaga kesehatan pada rumah sakit telah berupaya dengan sungguh-sungguh untuk menemukan cara pengobatan yang benar-benar tepat bagi pasien. Kesungguhan tersebut disebabkan pentingnya kesembuhan pasien bagi pihak rumah sakit sebagai ukuran keberhasilan dan terutama juga penting bagi pasien itu sendiri. Dengan demikian dapat disimpulkan bahwa tenaga kesehatan pada Unit Rawat Inap RSUD Kota Subulussalam telah berupaya dengan sungguh-sungguh menemukan cara pengobatan yang tepat bagi pasien, sehingga mencerminkan pelayanan yang berkualitas.

\section{Cara Meningkatkan Kualitas Pelayanan Publik Pada Unit Rawat Inap Badan Layanan Umum RSUD Kota Subulussalam}

RSUD Kota Subulussalam dinyatakan lulus akreditasi kategori perdana dari Komite Akreditasi Rumah Sakit (KARS) pada akhir tahun 2018.Meskipun baru lulus akreditasi tingkat perdana, Direktur RSUD Kota Subulussalam berkomitmen keadaan ini menjadi tonggak untuk peningkatan fasilitas dan pelayanan di RSUD Subulussalam. Adapun standar mutlak akreditasi rumah sakit menurut surat edaran KARS Nomor 861/ SE / KARS / VIII / 2017 tentang persyaratan mutlak kelulusan Akreditasi Rumah Sakit adalah:

1) Rumah Sakit dipimpin Oleh tenaga Medis (Dokter atau dokter gigi)

2) Rumah Sakit memiliki Ipal yang berizin

3) Rumah Sakit mengadakan Obat-obatan dari Jalur Distributor Resmi

4) Rumah Sakit melaksanakan pelayanan Kemotrapi sesuai standar 
5) Rumah Sakit memungsikan Staf medis yang memiliki STR dan SIP Yang valid.

Namun demikian bahwa pelayanan publik pada Unit Rawat Inap Badan Layanan Umum RSUD Kota Subulussalam masih dapat ditingkatkan hingga mencapai kategori sangat baik (Sirait, 2011; Rinaldi, 2012). Upaya yang dapat dilakukan untuk meningkatkan kualitas pelayanan tersebut adalah dengan memperbaiki hal-hal yang berkaitan dengan fasilitas ruangan dan komunikasi dengan pasien, sebagaimana dijelaskan berikut ini:

Ketersediaan Fasilitas, Ketersediaan fasilitas fisik pada rumah sakit masih tergolong kurang, dimana tempat tidur masih kurang banyak sementara alat kipas angin untuk mendingin ruangan juga masih kurang memadai. Disamping itu, rumah sakit juga belum dapat menyediakan ruangan VIP untuk pasian yang menghendaki ruang perawatan yang lebih pribadi. Fasilitas rumah sakit yang baik harusnya dapat menyediakan tempat tidur untuk semua pasien sesuai standar, sehingga pasien dapat menjalani perawatan dengan baik. Ruangan perawatan juga harus dijaga agar tidak gerah dengan menyediakan alat pendingin ruangan yang memadai, seperti kipas angin dalam jumlah yang dapat menjangkau seluruh ruangan. Disamping itu rumah sakit juga harus dapat memberikan pelayanan kepada pasien yang menghendaki ruangan pribadi yang memiliki fasilitas lebih baik dengan menyediakan ruangan VIP.

Kejujuran Dalam Perhitungan Biaya Pengobatan, Sebagian besar responden menyatakan bahwa rumah sakit belum menyediakan informasi secara baik tentang perhitungan biaya pengobatan, sehingga cenderung keluarga pasien merasa ragu. Sebelum dilakukan pengobatan dan mendapatkan pelayanan rawat inap, biasanya biaya pengobatan diperkirakan agar keluarga pasien mempunyai persiapan dalam hal biaya karena biaya tersebut harus dibayar walaupun pasien belum sembuh atau harus dirujuk ke rumah sakit lain yang peralatannya lebih baik. Dalam hal ini tarif jasa rumah sakit tidak diinformasikan melalui leaflet dan papan pengumuman, padahal itu penting untuk memudahkan pasien mengetahui biaya jasa rumah sakit.

RSUD Kota Subulussalam telah memiliki standart operational procedure (SOP) dalam hal pemberitahuan perhitungan biaya pengobatan kepada pasien baik perhitungan diawal dan diakhir. Akan tetapi perlunya pemberitahuan biaya pengobatan kepada pasien memasuki di pertengahan perjalanan pengobatan apabila biaya pengobatan akan melebihi anggaran yang sudah diberitahukan sebelumnya sehingga pasien tidak merasa terkejut dengan pembayaran diakhir.

Kemudahan Informasi Mengenai Jenis Layanan pada Rumah Sakit, Rumah sakit tidak menyediakan sumber informasi yang dapat memudahkan pasien untuk mengetahui jenis layanan yang terdapat pada rumah sakit. Sumber informasi pada rumah sakit adalah petugas yang secara khusus untuk memberikan informasi kepada pasien atau keluarganya, sedangkan informasi dalam bentuk tercetak yang dapat dibaca oleh pasien, tidak ada.

Berdasarkan SOP RSUD Kota Subulussalam belum menyediakan layanan informasi dalam bentuk tercetak dan sistem online untuk memudahkan masyarakat memperoleh informasi. Dengan demikian untuk mengatasi masalah tersebut maka sebaiknya pihak rumah sakit menyediakan informasi mengenai layanan yang terdapat pada rumah sakit 
dalam bentuk tercetakyang dapat dibaca oleh pasien, dan juga menyediakan akses informasi melalui internet sehingga pasien dan masyarakat umum dapat dengan mudah untuk merujuk pada rumah sakit tersebut.

Menurut Peraturan Menteri Kesehatan Republik Indonesia Nomor 4 Tahun 2018 tentang Kewajiban Rumah Sakit dan Kewajiban Pasien pada Pasal 2 ayat (1) berbunyi: Setiap Rumah Sakit mempunyai kewajiban:

a. Memberikan informasi yang benar tentang pelayanan Rumah Sakit kepada masyarakat;

b. Memberi pelayanan kesehatan yang aman, bermutu, antidiskriminasi, dan efektif dengan mengutamakan kepentingan pasien sesuai dengan standar pelayanan Rumah Sakit;

Kemampuan Tenaga Kesehatan Berkomunikasi Dengan Bahasa Yang Mudah Dipahami Oleh Pasien, Tenaga kesehatan pada rumah sakit sering mengungkapkan bahasa yang tidak dimengerti oleh pasien atau keluarganya, terutama jika menyangkut istilah kesehatan (Hidayat, 2015). Kondisi tersebut tentu akan menyulitkan karena pasien atau keluarganya tidak dapat menjawab dengan baik mengenai kondisi yang dialami atau dirasakan pasien sehubungan dengan penyakitnya. Oleh karena itu tenaga kesehatan pada rumah sakit perlu mengupayakan agar semua istilah-istilah kesehatan dapat diungkapkan dengan bahasa Indonesia, sehingga tidak membingungkan pasien atau keluarganya. Penggunaan bahasa tersebut sangat penting berkomunikasi agar tenaga kesehatan dapat memperoleh umpan balik yang akurat berupa informasi mengenai gejala penyakit sesuai dengan yang dirasakan oleh pasien.

Kemampuan Tenaga Kesehatan Menjalin Komunikasi Yang Harmonis Dengan Pasien, Tenaga kesehatan tidak mampu menjalin komunikasi yang harmonis dengan pasien dan keluarganya, karena perawat secara sengaja telah membuat jarak dengan pasien untuk menghindari pelayanan yang tidak fokus pada penyakit pasien. Padahal suasana yang lebih akrab dan harmonis justru akan sangat membantu pasien mengungkapkan secara bebas dan lepas mengenai gejala penyakit yang dirasakannya. Pembatasan komunikasi antara tenaga kesehatan dengan pasien justru menjadi faktor kendala aliran informasi, sehingga kurang mendukung dalam proses penyembuhan pasien. Oleh karena itu pihak rumah sakit perlu lebih membuka diri untuk lebih dekat dengan pasien dan keluarganya, sehingga masyarakat menjadi puas dalam mendapatkan pelayanan rumah sakit. Menurut Kepmenpan No. 25/M.PAN/2/2004 tentang Prosedur Umum Penyusunan Indeks Kepuasan Masyarakat bahwa Indeks Kepuasan Masyarakat (IKM) adalah data dan informasi tentang tingkat kepuasan masyarakat yang diperoleh dari hasil pengukuran secara kuantitatif dan kualitatif atas pendapat masyarakat dalam memperoleh pelayanan dari aparatur penyelenggara pelayanan publik dengan membandingkan antara harapan dan kebutuhannya. Survey IKM bertujuan untuk mengetahui tingkat kinerja unit pelayanan secara berkala sebagai bahan untuk menetapkan kebijakan dalam rangka peningkatan kualitas pelayanan publik selanjutnya (Rinaldi, 2012; Narita,_Warjio $\_$Agus 2016). 


\section{SIMPULAN}

Kualitas pelayanan publik pada Unit Rawat Inap RSUD Kota Subulussalam tergolong pada kategori baik. Bukti fisik kebersihan ruangan cukup baik, kepercayaan terhadap pelayanan cukup baik, ketanggapan cukup baik, kompetensi tenaga kesehatan cukup baik, kesopanan cukup baik, keamanan cukup dan upaya tenaga kesehatan untuk memahami penyakit pasien juga cukup baik. Tetapi masih ada unsur pelayanan yang kurang baik, yaitu ketersediaan fasilitas yang kurang baik, kurang imformasi/jujur dalam perhitungan biaya, serta komunikasi yang tidak bagus.

Untuk meningkatkan pelayanan maka perlu dilakukan perbaikan terhadap fasilitas, memperbaiki prosedur perhitungan biaya pengobatan, menyediakan sumber informasi yang dapat memudahkan pasien untuk mengetahui jenis layanan yang terdapat pada rumah sakit. Disamping itu tenaga kesehatan perlu melakukan komunikasi dengan mengungkapkan bahasa yang tidak dimengerti oleh pasien atau keluarganya, serta menjalin komunikasi yang harmonis dengan pasien dan keluarganya.

\section{DAFTAR PUSTAKA}

(2010). Manajemen Pelayanan Prima. Yogyakarta: Graha Ilmu.

Al-Assaf, A. F, (2009). Mutu Pelayanan Kesehatan (Prespektif Internasional) Kedokteran,. Jakarta: EGC.

Balitbang Kemenkes RI. (2013). Riset Kesehatan Dasar; RISKESDAS. Jakarta: Balitbang Kemenkes RI

Dumpapa, Y. (2010). Hubungan Lokasi, Biaya, Personil dan Informasi Rumah Sakit Dengan Keputusan Memilih Rawat Inap di RSUD Bitung. Manado: Program Pasca Sarjana Universitas Sam Ratulangi

Gasperz, Vincent. (2011). Total Quality Management. Jakarta: Gramedia Pustaka Utama.

Hardiyansyah, (2011). Kualitas Pelayanan Publik, Disertai Dengan Konsep, Dimensi, Indikator, Dan Implementasi. Yogyakarta; Gava Media.

Kasmir. (2006). Etika Costumer Service. Jakarta: PT. Raja GrafindoPersada.

Khairani, Laila. (2010). "Faktor - Faktor Yang Mempengaruhi Kepuasan Pasien Rawat Jalan RSUD Pasaman Babat”, Jurnal Ilmu Manajemen, diposting dari http:// www.pasca.unand.ac.id.

Lestari, Wijayanti Puji, (2014), "Analisis Faktor Penentu Tingkat Kepuasan Pasien di Rumah Sakit PKU Muhammaddiyah Bantul”, Jurnal Kedokteran Indonesia, di posting dari http://jounal.uii.ac.id

Moenir. (2006). Manajemen Pelayanan Umum di Indonesia. Jakarta; Bumi Aksara.

Moleong, Lexy J. (2010). Metodologi Penelitian Kualitatif. Bandung: Rosda Karya.

Mukarom, Zaenal \& Muhibudin Wijaya Laksana. (2015). Manajemen Pelayanan Publik. Bandung: CV Pustaka Setia

Narita, A.A.S,_Warjio ${ }_{\mathbf{k}}$ Agus S (2016) Analisis Kualitas Pelayanan Pada Kantor Dinas Pendapatan Provinsi Sumatera Utara UPT Medan Selatan, Jurnal Administrasi Publik, 6 (2): 87-96.

Ratminto \& Winarsih. (2007). Manajemen Pelayanan (Pengembangan Model Konseptual, Penerapan Citizen's Charter dan Standar Pelayanan Minimal). Yogyakarta: Pustaka Pelajar.

Rinaldi, R., (2012), Analisis Kualitas Pelayanan Publik (Studi pada Biro Umum Sekretariat Daerah Propinsi Sumatera Utara), Jurnal Administrasi Publik : Public Administration Journal, 1 (1): 22- 34

Rohman, Ahmad Ainur \& dkk. (2010). Reformasi Pelayanan Publik. Malang : Averroes Press.

Silalahi, Ulber. (2015). Metode Penelitian Sosial Kuantitatif. Bandung: Rafika Aditama.

Sinambela, Lijan Poltak. (2010). Reformasi Pelayanan Publik. Jakarta: Bumi Aksara.

Sugiyono. (2012). Metode Penelitian Kuantitatif, Kualitatif dan R\&D. Bandung: Alfabeta.

Tjiptono, F. (2009). Total Quality Management. Yogyakarta: Andi.

Tjiptono, F. (2011). Service Management, Mewujudkan Layanan Prima. Yogyakarta: Andi.

Rinaldi, R., (2012), Analisis Kualitas Pelayanan Publik (Studi pada Biro Umum Sekretariat Daerah Propinsi Sumatera Utara), Jurnal Administrasi Publik : Public Administration Journal, 1 (1): 22- 34

Sirait, R.S.M.P., (2011), Analisis Pelayanan Publik Terhadap Administrasi Penerbitan Akta Kelahiran (Studi Pada Dinas Kependudukan Kota Medan), Jurnal Administrasi Publik : Public Administration Journal : Public Admnistration Journal, 1 (2): 232-249

Hidayat, T.W. (2015), Analisis Berita Kesehatan di Media Massa terhadap Pelayanan Publik, Jurnal Simbolika: Research and Learning in Comunication Study, 1 (2): 142-157 
Khainuddin, Heri Kusmanto, Isnaini. Analisis Kualitas Pelayanan Publik Rawat Inap Pada Badan Layanan Umum Rumah Sakit Umum Daerah Kota Subulussalam

Simanjuntak, R.D., (2016), Pelayanan Kesehatandalam Pendekatan Komunikasi Antar Budaya (Studi Fenomenologi Pelayanan Kesehatan Dokter Kepada Pasien Di RSUP H. Adam Malik Medan), Jurnal Simbolika: Research Undang-Undang and Learning in Comunication Study, 2 (2): 156-166

Undang-Undang No. 25 Tahun 2009 tentang Pelayanan Publik

Undang-Undang RI Nomor 44 Tahun 2009 tentangRumahSakit.

Peraturan Presiden No. 12 Tahun 2013 tentang Jaminan Kesehatan

Keputusan Menteri Pendayagunaan Aparatur Negara No. 25 Tahun 2004 tentang Indeks Kepuasan Masyarakat. 